\title{
Considerations on geomorphological maps for territorial planning in the Modena Apennines (Northern Italy)
}

\author{
D. Castaldini ${ }^{1}$, A. Ghinoi ${ }^{2}$, and A. Maccaferri ${ }^{2}$ \\ ${ }^{1}$ Department of Earth Sciences, University of Modena and Reggio Emilia, Largo S. Eufemia 19, 41121 Modena, Italy \\ ${ }^{2}$ Professional Geologist Office, Viale Caduti in Guerra 1, 41121 Modena, Italy \\ Correspondence to: D. Castaldini (doriano.castaldini@unimore.it)
}

Received: 28 October 2011 - Accepted: 13 December 2011 - Published: 27 February 2012

\begin{abstract}
This contribution shows, through some examples, that the current instability processes sometimes do not completely correspond (concerning presence, location, state of activity and/or extent) with those mapped by PTCP Hydrogeological Hazard Maps, which is the document used by the Province Administration for its territorial planning.

The differences highlighted are due to different causes. One of them is the fact that the PTCP Hydrogeological Hazard Maps are practically derived from the Regional Geological maps in which superficial deposits have secondary importance, while bedrock and structural-tectonic aspects are given the highest relevance. Another cause is represented by the very active and intense geomorphological dynamics of the Apennines which may produce or reactivate instability conditions.
\end{abstract}

An important aspect to underline is that the PTCP Hydrogeological Hazard Maps identify areas with planning constraints, which have effects at a municipal scale; it does so by starting from a cartographical basis whose primary aim is not the definition of instability processes and whose updating is not homogeneous.

Taking into account this aspect, the PTCP Hydrogeological Hazard Maps should be updated not only on the base of traditional geological mapping, but also following the criteria of detailed geomorphological mapping which can precisely define the genesis, dynamics and morphometry of instability phenomena.

An important consideration, in relation to territorial planning, is that the PTCP Hydrogeological Hazard Maps should be used just as a "base document", which requires more necessary detailed deepening at the municipal scale, accomplished through accurate geomorphological mapping, at least for the areas that are going to be urbanized.
The geomorphological mapping should also update those elements of the landscape which could have changed from the official topographic base map.

Detailed geomorphological mapping, possibly undertaken with the methodology proposed in this paper, could be given in charge also to professional geologists in accordance with standard procedures set in collaboration with the Provincial Administration.

\section{Introduction}

The studies carried out by the authors of this paper during the last few years in the Modena and Bologna Apennines (Emilia Romagna Region) have allowed the highlighting of how, in several instances, the instability processes identified did not always match with those mapped by the Hydrogeological Hazard Maps of the Province-Coordinated Territorial Plan ("Carte del Dissesto del Piano Territoriale di Coordinamento Provinciale” or simply PTCP Hydrogeological Hazard Maps for this article); the latter are derived by other base maps to be described in Sect. 3 .

The main differences are related to the presence, location and/or state of activity of the slope instability phenomena which are the typical elements characterising instability processes.

It is important to underline how the contents of the PTCP Hydrogeological Hazard Maps have direct and constraining effects on the Municipalities' territorial planning so that, within the Emilia-Romagna Region, it is accomplished by the so called Municipal Structural Plans (Piani Strutturali Comunali, or PSCs) or by the former General Regulatory Plans (Piani Regolatori Generali, or PRGs). 
Following the PTCP regulations, PSCs or PRGs should improve the quality of data contained in the PTCP Hydrogeological Hazard Maps, reaching a higher level of accuracy and detail, but as a matter of fact, this seldom happens.

This contribution takes some of the studies carried out by the authors as examples to better understand what the main differences are about, analysing the reasons for those differences. From a practical point of view, some considerations are made regarding the assessment of geomorphological instability related to territorial planning.

\section{Geographical, geological and geomorphological setting of the Modena Apennines}

The southern sector of the Modena Province belongs to the Northern Apennines, whereas the northern sector belongs to the Po Plain. The Northern Apennines are a fold-and-thrust mountain chain derived from the post-Eocene collisional history between the European and African plates and from a complex, multi-staged evolution (Bettelli and De Nardo, 2001; Cerrina Feroni et al., 2002). The Modena Apennines range in altitude between about $150 \mathrm{~m}$ a.s.l., along the margin with the Po Plain, and $2000 \mathrm{~m}$ a.s.l., along the watershed between the Adriatic and Tyrrhenian sides of the chain.

The main watercourses of the Modena Apennines are the rivers Panaro (in the eastern sector) and Secchia (in the western sector) which collect waters from the central sector of the Northern Apennines; after a course through the Apennines (about $63 \mathrm{~km}$ and $58 \mathrm{~km}$ long, respectively) and the Po Plain they flow into the River Po (the longest river in Italy).

The main geological units forming the Modena Apennines are as follows (Bettelli et al., 1989):

(1) Tuscan Units, made up of Tertiary siliciclastic deepwater turbidites, continuously cropping out along the chain's axis; (2) Ligurian Units, made up of deep-sea, oceanic sediments including Jurassic ophiolites followed by thick sequences of Late Cretaceous to Middle Eocene calcareous or terrigenous turbidites; (3) the mainly terrigenous epiLigurian succession of Middle Eocene to Late Messinian age, unconformably resting on the previously deformed Ligurian Units; (4) the belt of Plio-Quaternary marine terrigenous deposits unconformably overlying the Ligurian Units and the epi-Ligurian succession and dipping under the alluvial deposits of the Po Plain.

The geomorphological features of the Modena Apennines, are the result of a series of processes which have been active over a long time (mainly from the Late Pleistocene) on different lithological types with changing climatic and geodynamic conditions in terms of recurrence, areal distribution and intensity.

In this territory, landforms and deposits, due to running waters, can be observed everywhere; valley-floor deposits are prevalently gravels. In response to various types of human disturbance, after the 1950s, the braided pattern of the main streams became canalised and deepened (Surian and Rinaldi, 2003; Castaldini and Ghinoi, 2008).

Along the Apennine margin the "calanchi", forms of erosion similar to badlands, can be clearly observed.

Structural landforms resulting from both regional tectonic evolution (also neo-tectonic) and lithological morphoselection have considerable prominence. On the slopes, Quaternary continental covers are made up of slope or eluvialcolluvial deposits. Slope instability processes are particularly important, especially mass movements. In the EmiliaRomagna Region, over 70000 landslides have been identified (APAT, 2007): from the typological point of view, all landslide types are represented (according to the classification by Cruden and Varnes, 1996). The most frequently recurring landslides, though, are complex ones, associating multiple rotational and roto-translational slides with earth flows; as regards the velocities, they are classified as slow to rapid. The high number of large and periodically reactivated landslides, found all over this sector of the Apennines, depends primarily on geological causes, linked to the quality of rock masses and their state of physical weathering. The physical causes consist essentially of intense and/or prolonged precipitation; also the importance of snowmelt among mass movement causes has been demonstrated (Bertolini and Pellegrini, 2001). The paper by Bertolini and Pellegrini (2001) does not indicate precise quantitative data, but more specific data can be found in a more recent publication by Pizziolo et al. (2008), where the authors calculated precipitation threshold curves for landslides which occurred in the past in some provinces of the Emilia-Romagna Region. The conclusions were that $84 \%$ of examined landslide activations occurred after a continuous rainfall lasting from 3 to 5 days: for those cases it is of great importance for the amount of soil saturation given by previous cumulative rainfall. $28 \%$ of the examined landslides were triggered by rainfall events with a return period of $2 \mathrm{yr}$ and $38 \%$ of the landslides examined by Pizziolo et al. (2008) which occurred after rainfall events with a return period from 2 and $10 \mathrm{yr}$. Extreme cases represent the $34 \%$, with a return period of rainfall events higher than $20 \mathrm{yr}$.

Regarding the contribution of snowmelt to landsliding, no quantitative correlations have been attempted so far by researches for the Emilia Apennines, this is likely because measurements of snowpack distribution, thickness and density have never been undertaken.

The earthquakes seem to be just the triggering cause of some landslides, whereas the intrinsic causes mainly result from the amount of precipitation in the preceding periods (Tosatti et al., 2008). Only in the past ten years has it been possible to recognise Deep-seated Gravitational Slope Deformations, which allowed the correct interpretation of forms previously ascribed to other causes.

Glacial landforms and deposits dated to the Last Glacial Maximum are found in the upper sector of the Modena Apennines, in which cryogenic and nivation landforms and deposits, are also widespread. 


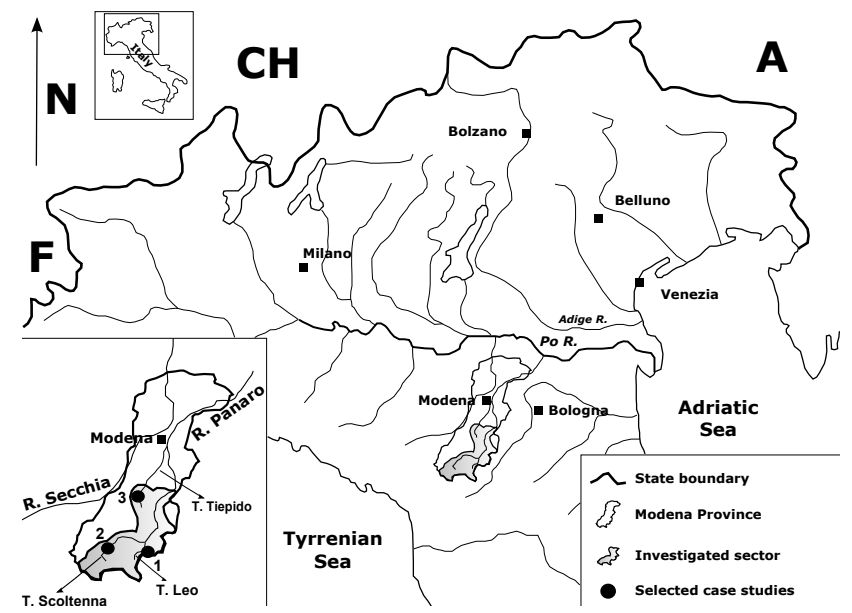

Fig. 1. Location of the selected case studies in the investigated sector of the Modena Province.

Finally, concerning man's activities in the mid-low Apennines, the irreparable damage to slopes caused by quarrying activities (raw materials for the ceramic tile industry) should be pointed out. In the upper Apennines, the impact determined by the setting up of ski pistes and ski-lifts should also be mentioned.

All the examples of instability case studies which will be described in this paper are located in the catchment basin of the Panaro River (Fig. 1).

\section{Legislative framework for hydrogeological hazard planning in the Emilia Romagna Region}

In Italy, hydrogeological hazard is managed through different instruments by the institutions, namely the State, Regions, Provinces and Municipalities.

The general reference plan for the Emilia-Romagna Region is the Hydrogeological Basin Plan (Piano Stralcio per l'Assetto Idrogeologico, PAI) by the Po-River Basin Authority (Autorità di Bacino del Fiume Po). That plan unifies the management, at basin scale, of the hydrogeological framework, coordinating all the measures adopted by previous planning documents.

The PAI identifies the fluvial safety buffers for the main water courses and defines the structural measures to be undertaken on those same water courses, on hillsides and on mountain areas; for the latter it outlines the areas at hydrogeological risk.

As concerns the Emilia-Romagna Region, in the early Seventies the Hydrogeological Hazard Maps (Carte del Dissesto) at the 1:25000 scale were realised, mainly through interpretation of aerial photographs.

In the early Nineties, those maps have been updated on the basis of the data derived from the Geological Map of the Emilia-Romagna Apennines (Carta Geologica
dell'Appennino Emiliano-Romagnolo), at the 1:10000 scale, realised by the Geological, Seismic and Soil Service of the Emilia-Romagna Region. The current hydrogeological hazard cartography is available for the whole Region on a webGIS portal (Regione Emilia-Romagna - servizio Geologico, Sismico e dei Suoli, web-site, 2011).

The current hydrogeological hazard cartography represents the knowledge basis taken as reference by the Po-River Basin Authority and by the Provinces to implement and improve their hydrogeological hazard maps.

Regarding the Modena Province, the PTCP Hydrogeological Hazard Maps and their associated regulations manage the instability framework within the territorial planning.

The PTCP Hydrogeological Hazard Maps are synthesis thematic maps classifying the instable zones as active or dormant landslides or as potentially instable areas (see Table 1). They also outline critical areas in relation to hydrogeological instability, toward which guidelines, prescriptions and directives are applied.

A peculiar situation for the Modena Province is the recently approved total correspondence between the instability framework of the PTCP Hydrogeological Hazard Maps and the one of the PAI which has, in fact, integrated all the instable areas outlined by the PTCP Hydrogeological Hazard Maps. Therefore, the latter represents the unique reference plan for the municipal urban planning with respect to the hydrogeological safety regulations.

In their territorial-planning phase, Municipalities can adopt, without any change, all data contained in the PTCP Hydrogeological Hazard Maps, but they can also improve them through detailed investigations.

Usually, the majority of Municipalities acquire the whole PTCP Hydrogeological Hazard cartography without making any change, not having enough economical resources to make improvements. In that way, the urban planning in the executive phase has to deal entirely with the management of the regulations and constraints related to the slope instability framework depicted by the PTCP Hydrogeological Hazard Maps.

\section{Study methodology and practical remarks}

The considerations on geomorphological maps for territorial planning, which are illustrated in this paper, are derived from the studies carried out for the implementation of detailed maps (1:5000/1:10000 scale) showing the geomorphological hazards affecting 16 main productive areas of the Panaro's mountain basin (Castaldini and Ghinoi, 2007a, b; Ghinoi and Castaldini, 2007; Castaldini and Ghinoi, 2009; Panizza, 2009) and the medieval village of Riola which is of historic, architectural and landscape importance and which has recently gained interest for possible tourist exploitation (Castaldini et al., 2008, 2010). 
Table 1. Legend of the PTCP Hydrogeological Hazard Maps (after Provincia di Modena, 2009).

\begin{tabular}{|c|c|c|}
\hline Zone & Category & Elements considered \\
\hline 1 & Areas affected by active landslides & $\begin{array}{l}\text { landslides which are currently active or that have been reactivated } \\
\text { since the last } 30 \mathrm{yr} \text { (rock-falls are also included). }\end{array}$ \\
\hline 2 & Areas affected by dormant landslides & $\begin{array}{l}\text { landslides that have not showed signs of activity since the last } \\
30 \mathrm{yr} \text { and that could be reactivated by their original causes; among } \\
\text { those are block slides, lateral spreads and Deep-seated Gravitational } \\
\text { Slope Deformations. }\end{array}$ \\
\hline 3 & Potentially instable areas & $\begin{array}{l}\text { quaternary deposits affected by evident superficial morphogenetic } \\
\text { processes such as creep, solifluction etc.; alluvial fans; areas af- } \\
\text { fected by relevant processes due to running water (erosion, floods, } \\
\text { etc.); naturally stabilized or relict landslides. }\end{array}$ \\
\hline \multicolumn{3}{|c|}{ Areas at high or very high hydrogeological risk } \\
\hline $4: \therefore$ & \multicolumn{2}{|l|}{ Houses to strengthen or to move away } \\
\hline 5 & \multicolumn{2}{|l|}{ Areas at very high hydrogeological risk } \\
\hline $6 \mathrm{~L}$ & Areas at landslide risk: high (R3) and & ery high $(\mathrm{R} 4)$ risk \\
\hline
\end{tabular}

The first step of the researches has been the acquisition of all available information and documents regarding the study areas and their surroundings subject to geomorphological instability. This has been carried out by: (a) historical and bibliographical research of past instability events; (b) analysis of thematic maps in order to identify areas affected by instabilities.

In a second step, past instability events have been studied through interpretation of aerial photographs, satellite images and maps of different scales and time periods as well as field surveys accompanied by enquiries among local inhabitants.

The third and final step has produced, for each one of the study areas, a geomorphological map and a database containing: the location of the study area (the administrative location, the hydrographical basin, the topographic maps at different scales and the aerial photographs/satellite images), geological/geomorphological data acquired from all bibliographic sources, information achieved through interpretation of aerial photographs/satellite images and field survey, comments and considerations. Differences found between the geomorphological map and the PTCP Hydrogeological Hazard Maps (Provincia di Modena, 2006) have been highlighted and the complete index of all documents produced (maps, geological profiles, photographs, etc.) has been added.

Practical remarks, regarding some important aspects that came out during the researches are listed below.

The effects of geomorphological hazard are essentially traceable back to geomorphological dynamics processes and their deriving forms and deposits, distinguished also according to their state of activity. Therefore, the first important aspect has regarded the concept of "state of activity" and its application.

It is known that many definitions of "state of activity" exist because that has an extremely important applicative matter. Without listing all the wide bibliography about this issue, in our researches, the criterion used by PTCP Hydrogeological Hazard Maps of Provincia di Modena (2006) and confirmed by Provincia di Modena (2009) to define the state of activity of instability processes has been adopted because it has direct law effects on the territorial planning of municipalities (see Sect. 3 and Table 1).

In order to identify the activity of the phenomena which occurred within the 30-yr limit (which separates "active" from "dormant" processes), the data from the first two steps of the methodology have been used.

Another important aspect has regarded the relative "old" age of the topographical base map used in our researches (Regional Technical Map of the Emilia Romagna Region, RTM, at the scale 1:5000). In that topographic base it was difficult to map instability processes, particularly their location and current extent; in fact, the most recent topographic base available is the edition of the RTM edited at the beginning of the 2000s. It is a planimetric update of just the structures and the infrastructures of the first-edition RTM built in the 1970s. Therefore, the general representation of morphology, of hydrography and of vegetation in the updated-edition RTM corresponds to an old situation. 


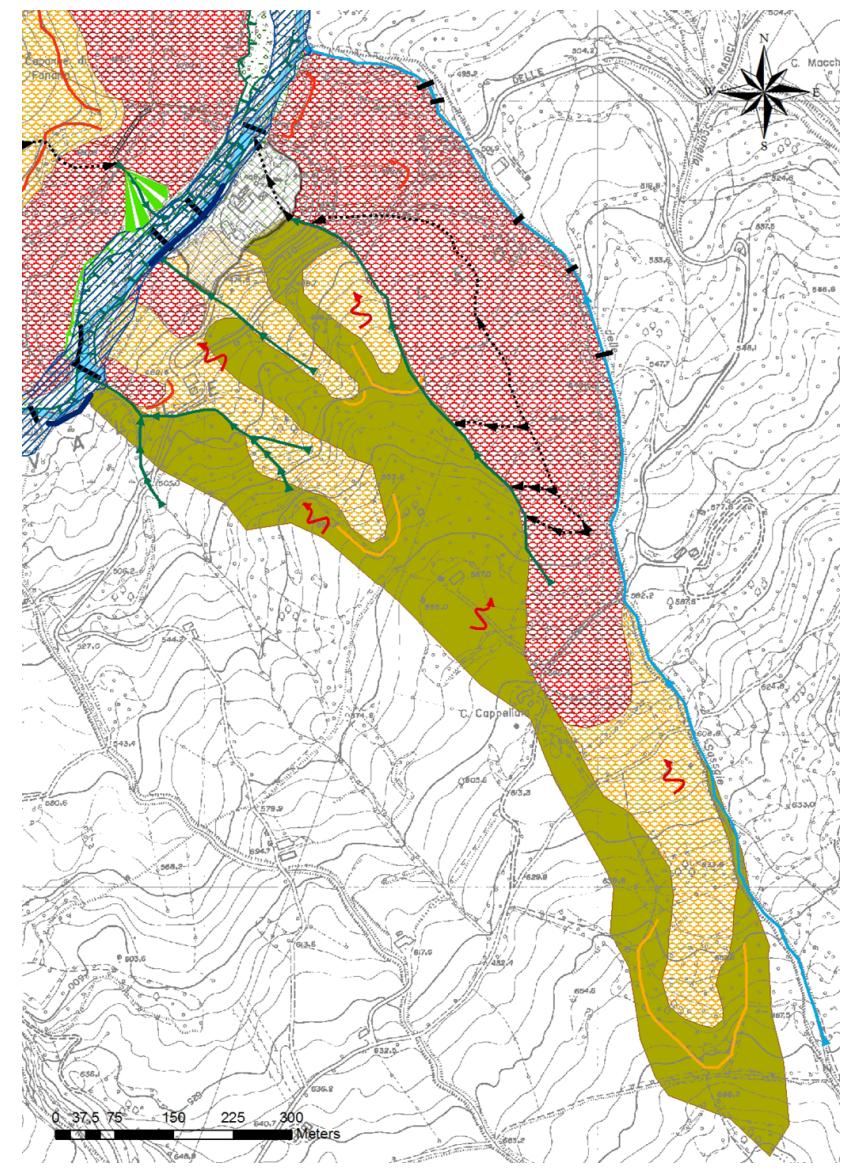

Fig. 2. Geomorphological map of the case study no. 1 in the valley of the Leo Torrent (after Castaldini and Ghinoi, 2009 modified). For legend see Fig. 3.

Comparing the results of field mapping with the topographic base, degradation/landslide scarps have undergone retrogressive evolution and hydrography has shown remarkable changes. Therefore, in order to map the instability scenario, the most recent satellite and aerial images, coupled with GIS, have been of great help.

\section{Examples of instability case studies}

This chapter illustrates some selected case studies of geomorphological instability, in different areas of the Panaro River basin, comparing the data acquired by the authors through detailed studies with the data contained in the PTCP Hydrogeological Hazard Maps.

\subsection{Zone surrounding a productive area in the valley of the Leo Torrent}

The following example considers the instability affecting a productive area (Industria Macellazione Valle del Leo) located on a fluvial terrace on the right flank of the Leo Torrent

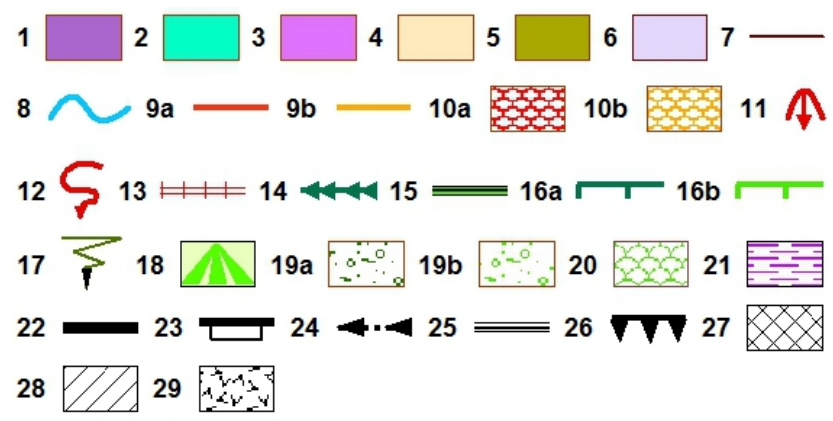

Fig. 3. Legend of the Geomorphological maps of the instability case studies. (1) VLR - Arenarie di Vallorsara: arenaceous-pelitic turbidites; (2) ABT - Formazione dell'Abetina Reale: marlstones or calcarenitic turbidites; (3) AVC - Unità Argilloso-calcarea: argillites; (4) MOD - Arenarie di Monte Modino: arenaceouspelitic turbidites; (5) APA - Argille a palombini: argillites with marlstones; (6) MVT - Brecce argillose della Val Tiepido-Canossa: breccias with clayey matrix; (7) lithological boundary; (8) torrent; (9) edge of degradation and/or landslide scarp: (a) active - (b) dormant; (10) landslide body: (a) active - (b) dormant; (11) unmappable landslide; (12) surface affected by solifluction; (13) trench or fissure; (14) gully; (15) abandoned river bed; (16) edge of torrential erosion scarp: (a) active - (b) dormant; (17) area affected by sheet erosion; (18) alluvial fan - dormant; (19) alluvial deposit (mainly gravelly) more than $1 \mathrm{~m}$ thick: (a) active - (b) dormant; (20) fluvioglacial, proglacial and alluvial deposit (Upper Pleistocene and Lower Holocene); (21) chaotic deposit of periglacial origin (thickness $>1 \mathrm{~m}$ ), glacis-like at some places (Upper Pleistocene); (22) check-dam; (23) slide-shaped check-dam; (24) artificial drainage; (25) containment wall; (26) edge of artificial scarp; (27) productive site; (28) artificial area (1.s.); (29) artificial debris.

(no. 1 in Fig. 1). Along the river bed, gravelly alluvial deposits mainly crop out, while the slope is exclusively made of alternations of shales and marlstones from the Argille a Palombini Formation (Ligurian Units). Hydrogeological hazard processes are represented by active and dormant complex landslides, by areas affected by solifluction, by rill erosion and by erosional processes due to the Leo Torrent (see Figs. 2 and 3).

The PTCP Hydrogeological Hazard Map of the same area is shown in Fig. 4 where only dormant landslides are identified. The most important difference comparing Figs. 2 and 4 is the larger extent of the landslide at the eastern limit of the study area; in fact, in Fig. 2 it covers also the northeastern ridge, mapped as bedrock by the PTCP Hydrogeological Hazard Map and by previous geological maps (Gelmini and Pellegrini, 1971; Amministrazione Provinciale di Modena, 1973; Regione Emilia-Romagna, 2001; Regione EmiliaRomagna - Servizio Geologico d'Italia, 2002). According to Castaldini and Ghinoi (2009) the ridge is a detrital deposit belonging to the main landslide body. Concerning its state of activity, the most active sector is indeed the one occupied by the newly identified deposit: there, the houses show 


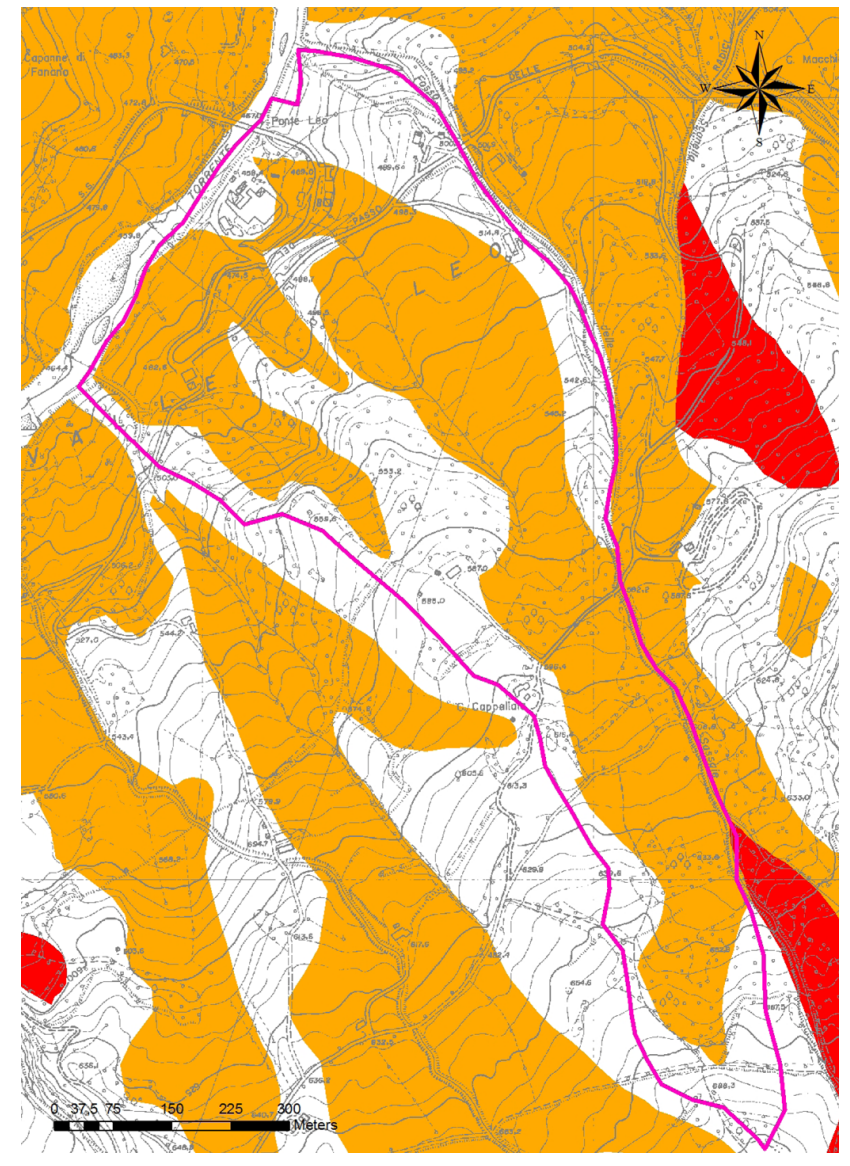

Fig. 4. PTCP Hydrogeological Hazard map of the case study n. 1 (Provincia di Modena, 2009). For legend see Table 1; purple line: boundary of the Fig. 2 Geomorphological map.

clear fractures and fissures caused, according to interviews to locals, by slope movements. The middle sector of the landslide, according to other local witnesses, has been active since the early Eighties; superficial and deep drainages has since then been reducing the magnitude of the movements. Only the upper sector of the landslide has been considered dormant.

Two small active landslides, due to the lateral erosion by the Leo Torrent, are mapped in the western sector of the study area, whereas the PTCP Hydrogeological Hazard Map identifies, in that same sector, just dormant landslides.

Considering susceptibility to slope instability, special attention should be paid to the landslide active in the northeastern sector, beyond the bridge across the Leo Torrent. In fact, its sudden, rapid reactivation, possibly triggered by the torrent lateral erosion, could reactivate the entire landslide body, including its mid-upper sectors.

As concerns the productive area, on the basis of the acquired data, it has never been affected by landslides movements, while in the Seventies it was flooded by the Leo Torrent waters. In spite of this flood event, the fluvial terrace

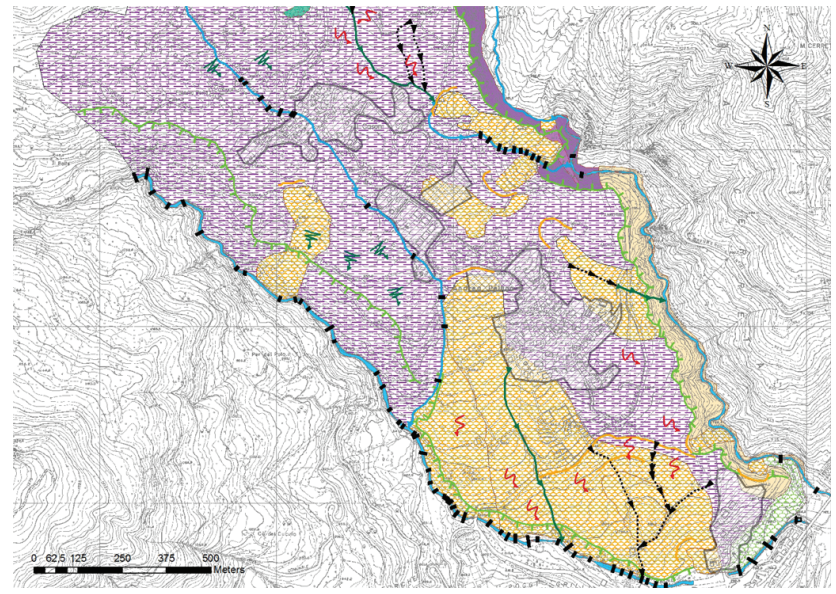

Fig. 5. Geomorphological map of the case study no. 2, S. Andrea Pelago village (catchment of the Scoltenna Torrent). For legend see Fig. 3 (after Panizza, 2009 modified).

on which the productive area is located, should have been indicated by the PTCP Hydrogeological Hazard Map as "potentially instable area" (see Table 1). After the flood event, an artificial embankment has been built on the edge of the fluvial terrace scarp in order to reduce the flood risk.

The analysis of the main cartographic differences between the maps of Fig. 2 and Fig. 4 reveals a substantial underestimate, in terms of presence, location, state of activity and extent of the instability phenomena, by the PTCP Hydrogeological Hazard Map.

\subsection{Zone surrounding the $S$. Andrea Pelago village, in the catchment of the Scoltenna Torrent}

The case study considered here regards the zone surrounding the village of S. Andrea Pelago, on the left flank of the Scoltenna Torrent (no. 2 in Fig. 1).

The area is located on a SE-dipping slope where calcareous-marly turbidites and arenaceous-pelitic turbidites crop out. According to Panizza (2009) the area is mainly characterised by a wide chaotic deposit of periglacial origin (see Fig. 5). These periglacial deposits are composed by a chaotic assemblage of calcareous-arenaceous boulders mixed with remnants of argillite layers in a prevalently pelite matrix. The thickness increases from 1-2 $\mathrm{m}$ in the upper sector to more than $10 \mathrm{~m}$ down valley.

Their origin is to be referred to the periglacial morphoclimatic environment which characterised this territory during the last glacial expansion, defined for this sector of the Apennines with the term "Tagliole" (Panizza, 2008): the absence or scantiness of vegetation along the slopes and the presence of gelifluction, flow and mass movement processes favoured by the seasonal presence of iced soil, cryoturbation and frostshattering, caused the degradation of the overhanging reliefs and a progressive accumulation of debris at their foot, as far 


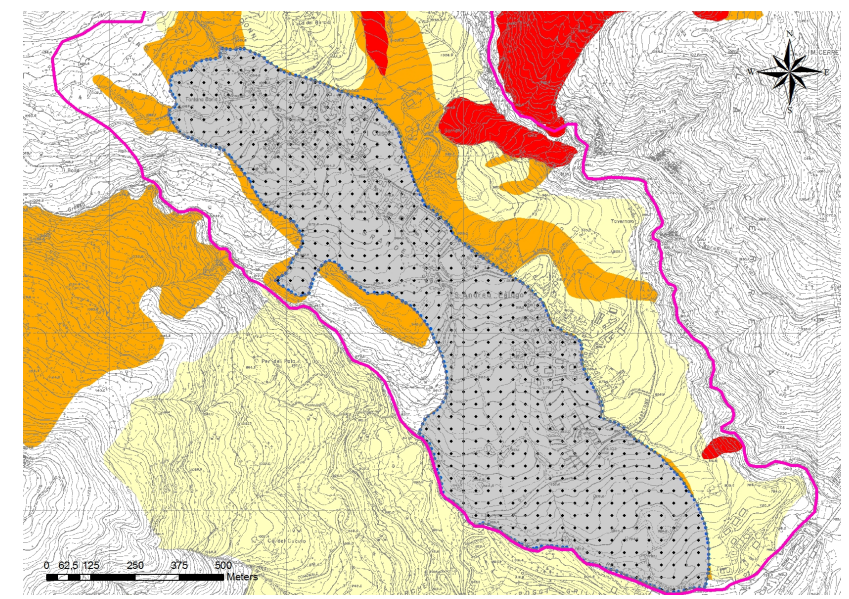

Fig. 6. PTCP Hydrogeological Hazard map of the case study no. 2 (Provincia di Modena, 2009). For legend see Table 1; purple line: boundary of the Fig. 5 Geomorphological map.

as the valley floor. In this way, a sheet of chaotic debris was formed which covered more or less homogeneously the slope of the S. Andrea Pelago area, thus, obliterating most of the pre-existing morphology; just some rocky spurs emerged from this detrital sheet.

Landslides (mainly earth flows) which have been affecting the periglacial deposits are isolated dormant slope movements, spatially far smaller than the periglacial deposit itself (Panizza, 2009). Some of these mass movements partially affect the village of S. Andrea Pelago causing its partial instability.

The interpretation proposed by Panizza (2009), thanks to a detailed geomorphological study and the knowledge of the local morphoclimatic evolution of the landscape, has led to a morphological picture substantially different from the one given by the PTCP Hydrogeological Hazard Map (Fig. 6).

In fact, while the PTCP Hydrogeological Hazard Map identifies a wide, unique dormant landslide, that led to classify the village of S. Andrea Pelago as an "Area at high hydrogeological risk", the Panizza (2009) interpretation reveals a highly reduced slope instability extent in favour of a wider relict deposit whose genesis dates back to a morphoclimatic environment not present anymore.

The geomorphological convergence of the periglacial deposit with a landslide deposit (Fig. 7) has led to a different interpretation the authors of Provincia di Modena (2009) and other previous authors (Annovi, and Simoni, 1993; Regione Emilia-Romagna - Provincia di Modena, 1998; Regione Emilia-Romagna - Servizio Geologico d'italia, 2002).

In this case study, the PTCP Hydrogeological Hazard Maps overestimate the instability picture of the S. Andrea Pelago village.

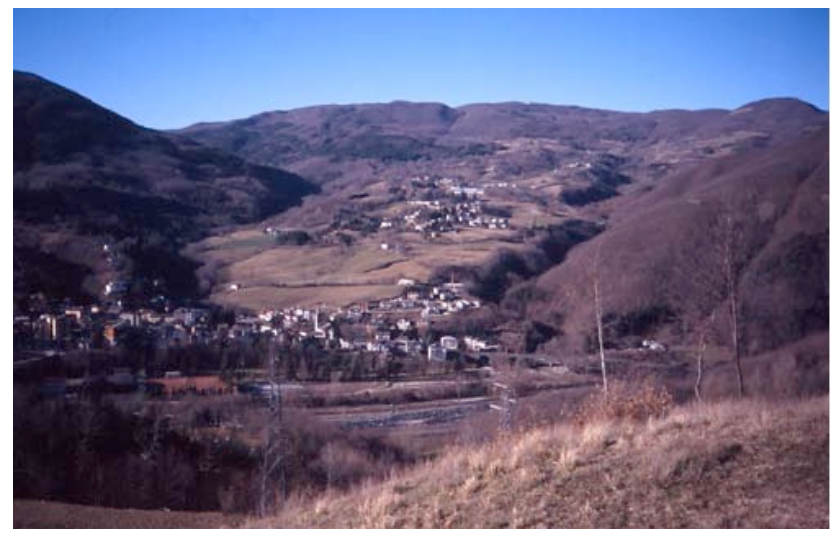

Fig. 7. Panoramic view of the slope of S. Andrea Pelago which is almost completely covered by glacis periglacial deposits. In the foreground the village of Pievepelago and the Scoltenna Torrent (photo by M. Panizza).

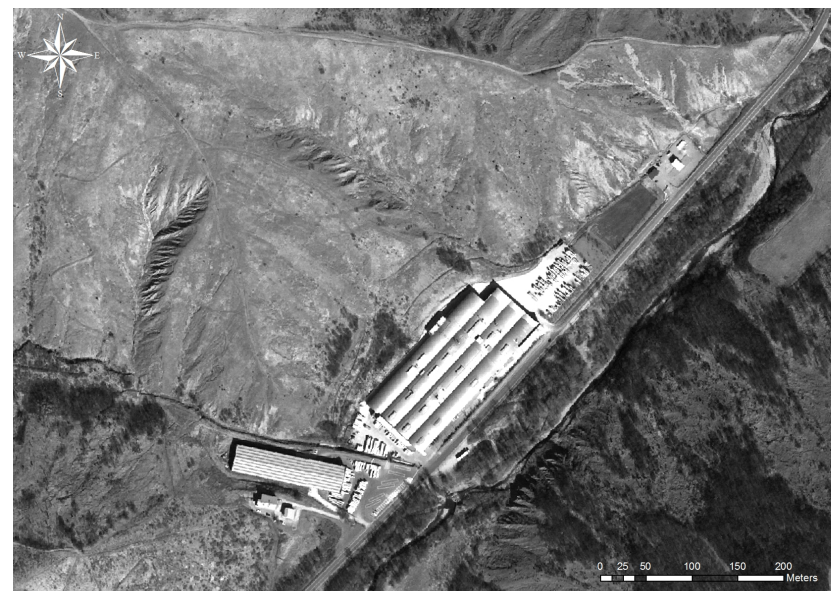

Fig. 8. Quick-Bird satellite image of the case study no. 3 in the valley of the Tiepido Torrent. Copyright: Digital GlobeTM, 2003, Telespazio per 1'Italia.

\subsection{Area surrounding a tile factory in the valley of the Tiepido Torrent}

The following example considers a productive area (the tile factory Ceramica Serra), located on a river terrace, in the valley bottom of the Tiepido Torrent (no. 3 in Fig. 1).

On the left side of the valley, marls and clayey marls of the Antognola Formation crop out. The interpretation of aerial photographs, of satellite images (Fig. 8) and field surveys have allowed us to reconstruct the geomorphological instability processes that affect the study area.

On the aerial photographs dated $1954 / 55$, a wide river terrace can be detected (on which the productive area has been built later on) on the left hydrographical side of the Tiepido Torrent. The torrent flows in a wide bed, braided and almost at the terrace level (which can therefore be flooded in case 


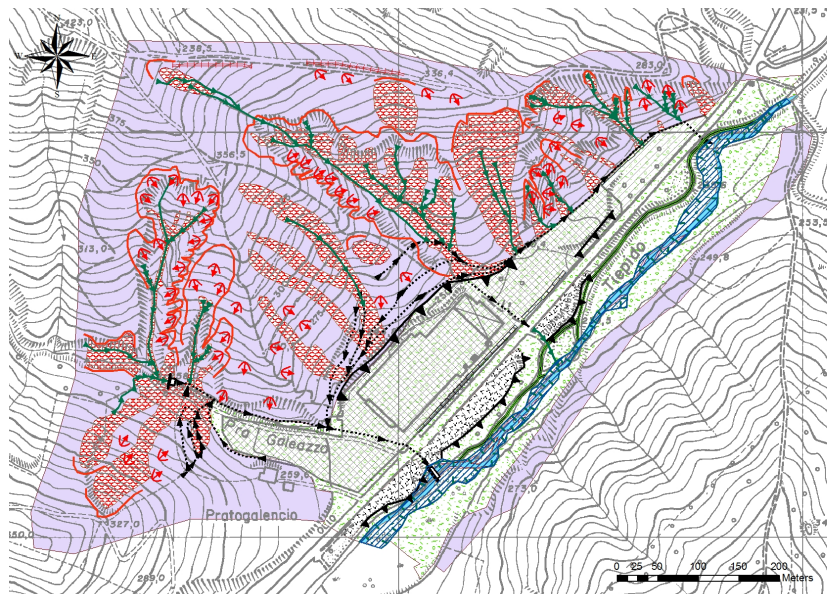

Fig. 9. Geomorphological map of the case study no. 3 in the valley of the Tiepido Torrent. For legend see Fig. 3.

of high waters). Upslope the alluvial terrace, several active earth-flows occur. In particular, inside the main impluvium, a long earth-flow is present whose toe has partially covered the alluvial terrace with a lobe that resembles that of an alluvial fan.

On the aerial photographs dated 1973, the structure of the Ceramica Serra was already present; in order to build it, the toe of the slope behind it and the toe of the still active earthflow were cut: on the Tiepido terrace, on the east side of the road, three deposits can be identified, made of debris produced by those construction works. The Tiepido Torrent has a bed far more narrow and deeper than that dated 1954/55, but it keeps some braided traits.

On aerial photographs dated $1988 / 89$ and 1994 , the toe of the earth-flow (still active), that lays on the terrace close to the factory, has been completely removed; the debris has been used to build the storage area for the tiles. The Tiepido river-bed has shifted south-eastwards and it is narrower, deeper and not braided.

The current instability scenario is shown in the geomorphological map (Fig. 9). In particular, the slope on the northwestern side of the factory is characterised by several active soil-slips that are conveyed inside the impluvia, creating earth-flow tongues.

The landslides mapped in the geomorphological map are more numerous than those mapped in the PTCP Hydrogeological Hazard Maps (Fig. 10) (Provincia di Modena, 2006, 2009) and in former publications (e.g., Regione EmiliaRomagna, 2003; Regione Emilia-Romagna - Servizio Geologico, Sismico e dei Suoli, 2006) and, therefore, the instability scenario needs to be carefully considered.

In fact, to mitigate the hydrogeological risk towards the tile factory, a network of superficial drains (which can be seen in Fig. 8) has been constructed on the slope behind in order to reduce waters infiltration, the principal cause of

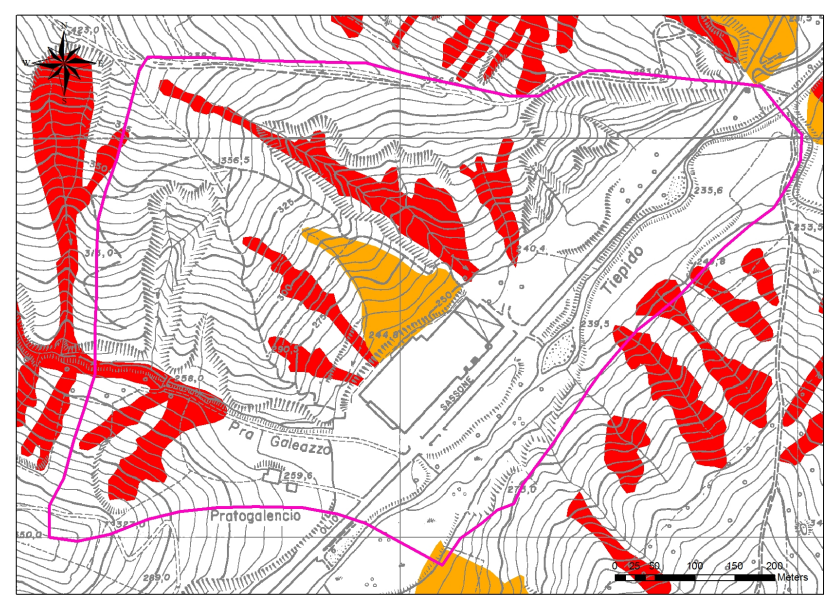

Fig. 10. PTCP Hydrogeological Hazard map of the case study no. 3 (Provincia di Modena, 2009). For legend see Table 1; purple line: boundary of the Fig. 9 Geomorphological map.

mass-movement reactivations. The artificial scarp behind the factory is occasionally affected by soil slips whose material can be rapidly removed. The Tiepido Torrent has changed its pattern from braided to monocursal, deepening its bed since $40 \mathrm{yr}$ (Pellegrini and Zarotti, 1975; Gasperi et al., 1979). The data from Castaldini and Ghinoi (2007b) show that the river bed mapped on the RTM is actually a paleo-river and that the current river bed flows shifted eastwards and $5 \mathrm{~m}$ deeper. Therefore, it can be safely concluded that fluvial processes connected to the Tiepido Torrent (floods and undercutting) do not represent an hazard for the Ceramica Serra.

\section{Conclusions}

This contribution has shown, through some examples, that the current instability processes sometimes do not completely correspond (concerning presence, location, state of activity and/or extent) with those mapped by PTCP Hydrogeological Hazard Maps (Provincia di Modena 2009), which is the document used by the Province Administration for its territorial planning.

The differences found between the detailed geomorphological mapping of the described case studies (as well as for other investigated areas) and the PTCP Hydrogeological Hazard Maps can be ascribable to the following causes:

1. the PTCP Hydrogeological Hazard Maps derive from the instability inventory of the Emilia-Romagna Region, which is in turn derived from the Regional Geological Cartography; in the latter, morphogenetic processes and deposits have been given a secondary importance with respect to lithology and tectonic-structural elements;

2. the updating of the instability inventory of the EmiliaRomagna Region is carried out through "occasional and 
patchy" studies, while the slope instability phenomena regularly occurring during the rainy seasons show that the Apennine territory is characterised by intense and active geomorphological dynamics and, therefore, organic and periodic researches would be necessary in order to update the slope instability picture.

An important aspect to underline is that the PTCP Hydrogeological Hazard Maps identify areas with planning constraints, which have effects at the municipal scale; it does so by starting from a cartographical basis whose primary aim is not the definition of instability processes and whose updating is not homogeneous.

Therefore, the following situations could occur: (i) allowing the urbanization on a landslide area because not identified as such; (ii) prevent or strongly limiting the urbanization on an area assessed as landslide area, while actually free of any instability process; (iii) prevent the urbanization of an area mapped as active landslide while clear morphological, historical, bibliographical and testimonial clues lead to interpret it as dormant, or even inactive.

Another relevant aspect regards the relative "old" age of the topographical base maps used (Regional Technical Map, RTM, at the scale 1:5000): on that base it was quite difficult to map instability processes, particularly their location and current extent.

To conclude, in relation to territorial planning, the PTCP Hydrogeological Hazard Maps should be used just as a "base document", which requires more necessary detailed deepening at the municipal scale, accomplished through accurate geomorphological mapping, at least for the areas that are going to be urbanized.

The accurate geomorphological mapping, whose importance for territorial planning has been recently underlined by Farabollini and Pambianchi (2011), should also update those elements of the physical landscape which could have changed from the official topographic base map (such as river courses, scarps, etc.) that, as it has been said beforehand, has been updated for just what concerns artificial features.

Detailed geomorphological mapping, possibly undertaken with the methodology proposed in this paper, could be given in charge also to professional geologists in the executive phases of planning where privates play a major role, in accordance with standard procedures set in collaboration with the Provincial Administration. This could be a feasible solution, also in terms of economic balance, in achieving a progressively more accurate slope instability mapping without putting heavy economic burdens on just the shoulders of public administrations.
Acknowledgements. The Authors are grateful to P. J. Bonachea (Departamento de Ciencias de la Tierra y Física de la Materia Condensada, Universidad de Cantabria, Spain) and to the anonymous referee for their critical review of this paper.

Edited by: F. Luino

Reviewed by: P. J. Bonachea and another anonymous referee

\section{References}

Amministrazione Provinciale di Modena: Il piano per la difesa del suolo, la sistemazione dei fiumi Secchia e Panaro e l'utilizzazione delle risorse idriche, Cooptip Modena, 161 pp., 1973.

Annovi, A. and Simoni, G.: Atlante dei centri abitati instabili dell'Emilia-Romagna, 4 - Provincia di Modena, CNR, Stab. Arti Grafiche Salomone, Roma, 50 pp., 1993.

APAT: Rapporto sulle frane in Italia, Il Progetto IFFI - Metodologia, risultati e rapporti regionali. Rapporti 78/2007 APAT, 681 pp., available at: http://www.apat.gov.it/site/it-IT/Rubriche/ Eventi/2007/Novembre/Rapporto_frane.html, 2007.

Bertolini, G. and Pellegrini, M.: The landslides of the Emilia Apennines (northern Italy) with reference to those which resumed activity in the 1994-1999 period and required Civil Protection interventions, Quaderni di Geologia Applicata, 8, 27-74, 2001.

Bettelli, G. and De Nardo, M. T.: Geological outlines of the Emilia Apennines (Italy) and introduction to the rock units cropping out in the areas of the landslides reactivated in the 1994-1999 period, Quaderni di Geologia Applicata, 8, 1-26, 2001.

Bettelli, G., Capitani, M., and Panini, F.: The mesoscopic structures of a strongly deformed multilayered sequence: a hypothesis of the origin of the "block-in-matrix" fabric and the layerparallel extension shown by Ligurian dismembered formations of the Baganza Supergroup outcropping in the Reggio Emilia and Modena Apennines, in: Post Congress Field Trip no. 3 - Excursion Guidebook - The chaotic rocks of the southeastern sector of the Emilia Apennines, First European Congress on Regional Geological Cartography and Information Systems, Bologna (Italy) 13-16 June 1994, 29-42, 1994.

Castaldini, D. and Ghinoi, A.: Geomorphological hazards assessment in the mountain basin of the Panaro River (Northern Apennines, Italy), Geophys. Res. Abstr., 9, SRef-ID:16077962/gra/EGU2007-A-08977, 2007a.

Castaldini, D. and Ghinoi, A.: Geomorphological Hazards Affecting Main Productive Areas in the Mountain Basin of the Panaro River (Modena Apennines, Italy): a Case Study, Analele Universitatii din Oradea, Seria Geografie, tom. XVII, Editura Universitatii din Oradea 2007, 11-20, 2007b.

Castaldini, D. and Ghinoi, A.: Recent morphological changes of the River Panaro (Northern Italy), Il Quaternario, Italian J. Quat. Sci., 21, 267-278, 2008.

Castaldini, D. and Ghinoi, A.: Studio della pericolosità geomorfologica in aree produttive del bacino montano del Fiume Panaro (Appennino Settentrionale), in: Ambiente geomorfologico e attività dell'uomo: Risorse, Rischi, Impatti, edited by: Agnesi, V., Atti II Conv. Naz. AIGeo, Torino 28-30/3/2007. Memorie della Società Geografica Italiana, 87, 87-98, 2009.

Castaldini, D., Ghinoi, A., and Maccaferri, A.: Analisi di dettaglio della pericolosità geomorfologica del borgo medievale di Riola 
di Labante (Appennino Bolognese), Il Geologo dell'Emilia Romagna, Anno VIII/2008, n. 32 - Nuova Serie, 5-18, 2008.

Castaldini, D., Ghinoi, A., and Maccaferri, A.: Geomorphological hazard assessment of the Area of the Medieval Village of Riola di Labante (Bologna Apennines, Northern Italy), Studia Universitatis Babes-Bolyai, Geographia, LV, 1, 5-18, 2010.

Cerrina Feroni, A., Martelli, L., Martinelli, P., Ottria, G., and Catanzariti, R.: Carta Geologico Strutturale dell'Appennino EmilianoRomagnolo, Scala 1:250.000, Regione Emilia-Romagna-CNR, S.EL.CA., Firenze, 2002.

Cruden, D. M. and Varnes, D. J.: Landslide Types and Processes, in: Landslides Investigation and Mitigation, edited by: Turner, A. K. and Schuster, R. L., Special Report 247, 3, 36-75, Transportation Research Board, National Academy Press, Washington, DC, 1996.

Farabollini, P. and Pambianchi, G.: La geomorfologia ed il rilevamento geomorfologico applicato alla pianificazione territoriale: uno strumento di previsione, prevenzione e controllo del paesaggio naturale ed antropico, Geologia Tecnica and Ambientale, 1/11, 32-41, 2011.

Gelmini, R. and Pellegrini, M.: Le frane del bacino del Panaro, Atti della Società dei Naturalisti e Matematici di Modena, Vol. C, 140, 1971.

Ghinoi, A. and Castaldini, D.: Studio della pericolosità geomorfologica in aree produttive del bacino montano del Fiume Panaro (Appennino Settentrionale), AIGeo, II Conv. Naz., Ambiente geomorfologico e attività dell'uomo: Risorse, Rischi, Impatti, Torino 28-30/3/2007. ARPA Torino, 60-61, 2007.

Panizza, M.: Pievepelago e le sue montagne nell'età glaciale, Rassegna Frignanese, 37(2007), 273-285, 2008.

Panizza, M.: Geomorfologia periglaciale dell'area di S. Andrea Pelago (Appennino Modenese), in: Ambiente geomorfologico e attività dell'uomo: Risorse, Rischi, Impatti, edited by: Agnesi V., Atti II Conv. Naz. AIGeo, Torino 28-30/3/2007. Memorie della Società Geografica Italiana, 87, 393-402, 2009.

Pizziolo, M., Del Maschio, L., Gozza, G., and Pignone, S.: Determinazione di soglie pluviometriche per l'innesco di frane in Emilia - Romagna, Il Geologo dell'Emilia-Romagna, 29, 21-27, 2008.
Provincia di Modena: Piano Territoriale di Coordinamento Provinciale, "Carta del dissesto", Area programmazione e Pianificazione Territoriale, Area Ambiente e Sviluppo Sostenibile, 1999.

Provincia di Modena: Piano Territoriale di Coordinamento Provinciale, Variante di adeguamento in materia di dissesto idrogeologico ai Piani di Bacino dei fiumi Po e Reno (adottato con deliberazione del Consiglio Provinciale no. 16 del 22/02/2006), Area programmazione e Pianificazione Territoriale, Area Ambiente e Sviluppo Sostenibile, 2006.

Provincia di Modena: 2009 PTCP, Piano Territoriale di Coordinamento Provinciale, Variante di adeguamento in materia di dissesto idrogeologico ai Piani di Bacino dei fiumi Po e Reno (approvato con delibera di Consiglio Provinciale no. 46 del 18/03/2009), Area programmazione e Pianificazione Territoriale, 2009.

Regione Emilia-Romagna - Provincia di Modena: Rischio da frana. Schede monografiche dei siti a rischio da frana, 13 Comune di Pievepelago, Centro Stampa Provincia di Modena, 1998.

Regione Emilia-Romagna: Carta geologica regionale 1:25000, Fanano 236SO, Foglio 236 Pavullo nel Frignano, S.EL.CA. srl, Firenze, SYSTEMCART, Roma, 2001.

Regione Emilia-Romagna - Servizio Geologico d'Italia: Carta geologica d'Italia scala 1:50000, F. 235 Pievepelago, A.T.I. tra S.EL.CA. srl, Firenze, SYSTEMCART, Roma, 2002.

Regione Emilia-Romagna: - servizio Geologico, Sismico e dei Suoli, available at: http://www.regione.emilia-romagna.it/wcm/ geologia/canali/cartografia/sito_cartografia/sito_cartografia.htm, 2011.

Surian, N. and Rinaldi, M.: Morphological response to river engineering and management in alluvial channels in Italy, Geomorphology, 50, 307-326, 2003.

Tosatti, G., Castaldini, D., Barbieri, M., D'amato Avanzi, G., Giannecchini, R., Mandrone, G., Pellegrini, M., Perego, S., Puccinelli, A., Romeo, R. W., and Tellini, C.: Factors of seismicallyrelated landslides in the Northern Apennines, Italy, Revista de Geomorfologie, 10, 3-19, 2008. 